

J Epilepsy Clin Neurophysiol 2005; 11(3):141-144

\title{
Mesial Temporal Lobe Epilepsy Syndrome: An Updated Overview
}

\author{
Fernando Cendes \\ Departamento de Neurologia, FCM/UNICAMP, Campinas, SP
}

\begin{abstract}
Mesial temporal lobe epilepsy (MTLE) is the most common form of partial epilepsy in young adults and also the most frequent type of epilepsy reported in surgical series worldwide. Mesial temporal lobe sclerosis (MTS) is the major underlying cause of MTLE, and it is present in $60-70 \%$ of patients with MTLE who undergo surgery for treatment of medically refractory seizures. Pathogenetic mechanisms underlying this distinct hippocampal pathology remains undetermined. Recent findings suggest a developmental malformation of hippocampus (inherited or acquired) that in association with subsequent injury (e.g. trauma, infection, complex febrile seizures) could develop ongoing seizures, resulting in the full-blown neuropathological features of MTS. Genetic background, age and type of initial precipitating injury, and vulnerability related to programmed cell death pathways are probable mechanisms involved in the development of MTS. Definitions for medical intractability may vary among centers, but usually include failure to achieve seizure control with two or more AEDs with adequate dosage and posology. The decision as to when one should perform surgery in patients with MTLE is a relevant issue that needs more investigation. Recent evidence discussed in this review indicates that longer duration of uncontrolled seizures is associated with an increased risk of unsuccessful surgery.
\end{abstract}

Key words: temporal lobe epilepsy, seizures, surgical treatment, hippocampal sclerosis, mesial temporal sclerosis, pathophysiology, magnetic resonance imaging.

\section{RESUMO}

Epilepsia do lobo temporal mesial: uma visão atualizada

Epilepsia de lobo temporal mesial (ELTM) é a forma mais comum de epilepsia parcial em adultos jovens e também a mais freqüente nas séries cirúrgicas mundiais. Esclerose mesial temporal (EMT) é a principal causa de ELTM; presente em $60-70 \%$ dos pacientes submetidos ao tratamento cirúrgico para crises refratárias. Os mecanismos patogênicos desta forma distinta de lesão hipocampal permanecem incertos. Achados recentes sugerem uma malformação do desenvolvimento do hipocampo (hereditária ou adquirida) que em associação com insultos subseqüentes (ex. trauma, infecção, crises febris complexas) poderiam provocar crises recorrentes, resultando nas características neuropatológicas da EMT. Substrato genético, idade e tipo de insulto precipitante inicial e vulnerabilidade relacionada a mecanismos de morte celular programada são prováveis mecanismos envolvidos no desenvolvimento da EMT. Definição de resistência ao tratamento clínico pode variar entre centros especializados, mas geralmente inclui falha no controle de crises após dois ou mais esquemas adequados de drogas antiepilépticas. A decisão de quando realizar um tratamento cirúrgico em pacientes com ELTM é questão relevante e necessita ser investigada com maior profundidade. Evidência recente discutida nesta revisão indica que duração prolongada de crises não controladas se associa a um maior risco de falha no tratamento cirúrgico.

Unitermos: epilepsia de lobo temporal, crises, tratamento cirúrgico, esclerose hipocampal, esclerose mesial temporal, fisiopatologia, ressonância magnética. 
Mesial temporal lobe epilepsy (MTLE) is the most common form of partial epilepsy in adults ${ }^{(1)}$, and it is estimated that it represents about $40 \%$ of all epilepsies in this age range. It can be sporadic, usually with positive family history, or it can present with clear familial recurrence ${ }^{(2)}$.

Causes of MTLE include hippocampal sclerosis (HS), small foreign tissue lesions such as hamartomas or glial tumors, vascular and congenital malformations, and gliotic lesions due to trauma or infections.

The terms "Ammon's horn sclerosis", "HS", and "mesial temporal sclerosis (MTS)" are often used interchangeably. The term "sclerosis" is originally a macroscopic and descriptive one: it indicates shrinkage and induration of the structure. Histologically, it implies selective neuronal loss with secondary astroglial proliferation that affects various sectors of the hippocampus to a different degree: the most vulnerable to damage are the endfolium (sector CA4), and sectors CA3 and CA1, while the granule cells of the dentate gyrus, sector CA2 and subiculum are the most resistant ${ }^{(3-5)}$. This cell loss, if sufficiently pronounced, will appear in MRI scans as a reduced volume or shrinkage of the hippocampus, frequently associated with changes in signal intensity. MTS is a histopathological term that indicates neuronal loss and gliosis involving the hippocampus, and often also the amygdala, uncus and parahippocampal gyrus ${ }^{(3-5)}$. Therefore, the term MTS is more comprehensive than HS and perhaps would fit better when discussing pathophysiologic mechanisms, MRI findings, or clinical spectrum of the condition. HS would be more appropriate when discussing histopathological findings from specimens that include mainly, or sometimes, only hippocampal tissue. This is the approach that will be used in this review.

\section{PATHOPHYSIOLOGY OF MTLE ASSOCIATED WITH MTS}

MTS is the major underlying cause of MTLE, and it is present in $60-70 \%$ of patients with MTLE who undergo surgery for treatment of medically refractory seizures. Pathogenetic mechanisms underlying this distinct hippocampal pathology remains undetermined. Several studies have shown a significant relationship between history of prolonged febrile seizures (FS) in early childhood and MTS. However, population based studies have not shown a significant relationship between FS early in life and subsequent $\operatorname{MTLE}^{(6 ; 7)}$. The interpretation of these observations remains controversial $^{(8)}$. One possibility is that early FS damages the hippocampus and is therefore a cause of MTS. Alternatively; a child may have prolonged FS because the hippocampus was previously damaged due to a prenatal/perinatal insult or genetic predisposition.
Recent studies have shown that prolonged and focal FS can produce acute hippocampal injury that evolves to hippocampal atrophy and that complex FS can actually originate in the temporal lobes in some children ${ }^{(9)}$. MRI studies in familial MTLE demonstrated magnetic resonance imaging (MRI) evidence of MTS in patients with benign epilepsy and seizure remission, or even individuals who had a single seizure, suggesting that the relationship between MTS and severity of TLE might be more complex than previously suspected ${ }^{(1,2,8,10,11)}$. MTS most likely has different causes and results from complex interactions among genetic and environmental factors. Recent molecular neuropathological studies focusing on developmental aspects of hippocampal organization revealed two intriguing findings in HS specimens of MTLE patients who underwent surgery: (i) The persistence of Cajal-Retzius cells in HS patients points towards an early insult and an altered Reelin signaling pathway and (ii) increased neurogenesis in and abnormal architectural organization of the dentate granule cell layer can be observed in young patients with early hippocampal seizure onset. These findings suggest a developmental malformation of hippocampus (inherited or acquired) that in association with subsequent injury (e.g. trauma, infection, FS) could develop ongoing seizures, resulting in the full-blown neuropathological features of $\mathrm{HS}^{(12)}$. Genetic background $^{(2)}$, age and type of initial precipitating injury ${ }^{(13,14)}$, vulnerability related to programmed cell death pathways ${ }^{(15)}$ are probable mechanisms involved in the development of HS.

\section{DIAGNOSTIC PRINCIPLES}

The first habitual seizures usually occur in late childhood or early adolescence. The initial ictal event may be a generalized convulsion or a complex partial seizure. Complex partial seizures are usually preceded by an aura (simple partial seizure); typically involving rising epigastric sensation associated with an emotional disturbance such as fear. Other psychic and autonomic symptoms are also seen, and some patients can have olfactory or gustatory sensations. Auras typically occur in isolation, as well as in association with complex partial seizures, and patients may recall occasional auras years before they experienced the first habitual complex partial seizure. The complex partial seizure commonly begins with a motionless stare and oroalimentary automatisms (eg, lip smacking, chewing), during which the patient may be unresponsive. Gestural and reactive automatisms, that can be ictal or postictal, are also common. When posturing of one extremity occurs, it is contralateral to the side of ictal onset. Seizures typically last about one minute or less. There are no definitive characteristics that distinguish complex partial 
seizures reflecting MTLE from complex partial seizures generated in the anterior portion of the temporal lobe or due to mesial temporal lesions other than MTS. Neurological examination is usually normal with the exception of memory deficits. Interictal electroencephalogram (EEG) findings in patients with MTLE typically include unilateral or bilaterally-independent mesial temporal spikes, best seen with basal (sphenoidal, inferior temporal) derivations. Ictal EEG recordings usually reveal ictal onset consisting of rhythmic 5 to $7 \mathrm{~Hz}$ activity in one midinferomesial temporal region, but there may be variations in this pattern. High-resolution MRI often demonstrates unilateral or bilateral hippocampal atrophy associated with hypertintense T2 signal in one or both hippocampi sometimes extending to amygdala or other medial temporal structures. These findings are highly specific for MTS. The same temporal lobe is usually hypometabolic on interictal FDG-PET (Positron emission tomography). It has been widely accepted, based on large series of surgical patients, that there is a strong correlation between MTS and the severity of the epilepsy. In addition, MTS identified by MRI has been associated with poor control of seizures by antiepileptic medication. However, the findings of MRI abnormalities in patients with good outcome or seizure remission, indicates that MTS is found not only in patients with medically refractory mesial $\operatorname{TLE}^{(1,2,8,10,16)}$. Evidence for this has already been hinted at in the literature, including descriptions of sporadic patients with $\mathrm{MTS}^{(17)}$. Furthermore, there are upcoming MRI evidence of MTS acquired in adulthood not necessarily associated with a poor seizure control ${ }^{(11)}$.

\section{THERAPEUTIC PRINCIPLES}

Carbamazepine and/or phenytoin as monotherapy are the appropriate medications for management of MTLE. Higher serum levels than those used for generalized seizures may be necessary, and medication should be increased until seizures stop or unacceptable side effects occur. Oxcarbazepine has an efficacy similar to that of carbamazepine, but patients may tolerate higher dosages with fewer side effects, and in some individuals this can make a difference in seizure control. Valproate, topiramate, or lamotrigine are of benefit when carbamazepine and phenytoin fail. Combination of drugs are usually ineffective, with the exception of clobazam associated with carbamazepine or phenytoin ${ }^{(18)}$. When seizures become refractory to medical treatment, they are unlikely to remit spontaneously. With long duration of uncontrolled seizures, increasing memory problems and other behavioral disturbances are usually reported. This sequence of events suggests that MTLE may be a progressive epileptic disorder ${ }^{(11)}$. Because of the psychosocial consequences of disabling epilepsy in adolescence and early adulthood, patients who may have MTLE should be referred to epilepsy centers as soon as it is apparent that control cannot be achieved with first-line medications. These patients are excellent candidates for surgical treatment, with a great chance $(80-90 \%)$ of becoming free of disabling seizures. Psychosocial intervention is also important in the management of many patients with mesial TLE, and is particularly important for rehabilitation following successful surgery.

\section{NATURAL HISTORY OF EPILEPSY AND RELEVANCE OF EARLY SURGICAL TREATMENT FOR EPILEPSY}

Information on the natural history of the epilepsies is confounded by almost inevitable therapeutic intervention that most likely alters the clinical course. However, in some situations the timing of this therapeutic intervention itself provides important information. A major study on prognosis in epilepsy listed the following among the risk factors for an adverse outcome: a young age at onset, more seizures prior to the first visit to a physician, and a longer duration of illness ${ }^{(19)}$. Most subsequent studies have confirmed these findings ${ }^{(20)}$. It can be argued, however, that the poor prognosis for patients whose seizures take longer to control, or who have more frequent seizures, is due to more severe epilepsy initially, rather than the occurrence of seizures per se ${ }^{(21)}$. Prognosis in these studies also depended on other features such as neurological deficits and underlying etiology ${ }^{(22)}$, that clearly reflect the severity of the epileptogenic process from start. Consequently, these data do not directly address the issue of the progressive nature of epilepsy ${ }^{(11)}$.

For the approximately 20\%-30\% of patients with epilepsy that are not well controlled with antiepileptic drugs (AEDs), surgery is worth considering when the patient's seizures arise from an area that can be surgically treated without causing unacceptable neurological deficits $^{(23)}$.

Definitions for medical intractability may vary among centers, but usually include failure to achieve seizure control with two or more AEDs with adequate dosage and posology. The decision as to when one should perform surgery may be more difficult and controversial, unless in extreme situations, such as in the presence of a growing tumor or in children with catastrophic epilepsies that are amenable to surgical resection. In a recent publication, Yoon et al. ${ }^{(24)}$ showed that duration of preoperative epilepsy of more than 20 years and age at surgery over 30 years were associated with an increased risk of recurrence of seizures. Unfortunately, only few patients had surgery within the first 10 years of their epilepsy which make it difficult to evaluate 
if earlier intervention would have offered these patients better prognosis for seizure freedom ${ }^{(25)}$. Traditionally, physicians, including many neurologists, have considered epilepsy surgery the last treatment option for patients with partial epilepsies. The average duration of surgically treatable epilepsy among young and middle-aged adults referred for epilepsy surgery at major adult epilepsy centers is about 20 years ${ }^{(25,26)}$. Age at surgery per se may not be the only factor to influence prognosis. For example, Berg et al. ${ }^{(27)}$ showed that patients with early childhood seizure onset have long latencies before developing refractory epilepsy, whereas older patients have shorter latencies. A better definition of when patients with partial epilepsy become refractory is of foremost importance for more 'aggressive' medical treatment or earlier surgical intervention in a given patient. This is particularly important in the context of MTLE.

\section{REFERENCES}

1. Cendes F, Kahane P, Brodie MJ, Andermann F. The mesio-temporal lobe epilepsy syndrome. In: Roger J, Bureau M, Dravet C, Genton P, Tassinari CA, Wolf P, editors. Epileptic syndromes in infancy, childhood and adolescence. $3^{\text {rd }}$ ed. Eastleigh UK: John Libbey \& Co Ltd; 2002. p.513-30.

2. Kobayashi E, Lopes-Cendes I, Guerreiro CA, Sousa SC, Guerreiro MM, Cendes F. Seizure outcome and hippocampal atrophy in familial mesial temporal lobe epilepsy. Neurology 2001; 56: 166-72.

3. Gloor P. Mesial temporal sclerosis: historical background and an overview from a modern perspective. In: Luders H, editor. Epilepsy surgery. New York: Raven Press; 1991. p.689-703.

4. Meencke HJ, Veith G. Hippocampal sclerosis in epilepsy. In: Luders H, ed. Epilepsy surgery. New York: Raven Press; 1991. p.705-15.

5. Bruton CJ. The neuropathology of temporal lobe epilepsy. New York: Oxford University Press; 1988.

6. Camfield CS, Camfield PR, Gordon K, Wirrell E, Dooley JM. Incidence of epilepsy in childhood and adolecesce - A populationbased study in Nova Scotia from 1977 to 1985. Epilepsia 1996; 37:19-23.

7. Camfield P, Camfield C, Gordon K, Dooley J. What types of epilepsy are preceded by febrile seizures? A population-based study of children. Dev Med Child Neurol 1994; 36:887-92.

8. Cendes F. Febrile seizures and mesial temporal sclerosis. Curr Opin Neurol 2004; 17:161-64.

9. VanLandingham KE, Heinz ER, Cavazos JE, Lewis DV. Magnetic resonance imaging evidence of hippocampal injury after prolonged focal febrile convulsions. Ann Neurol 1998; 43:413-26.

10. Kobayashi E, D’Agostino MD, Lopes-Cendes I, Berkovic SF, Li ML, Andermann E et al. Hippocampal atrophy and T2-weighted signal changes in familial mesial temporal lobe epilepsy. Neurology 2003; 60:405-9.
11. Cendes F. Progressive hippocampal and extrahippocampal atrophy in drug resistant epilepsy. Curr Opin Neurol 2005; 18:173-77.

12. Blumcke I, Thom M, Wiestler OD. Ammon's horn sclerosis: a maldevelopmental disorder associated with temporal lobe epilepsy. Brain Pathol 2002; 12:199-211.

13. Mathern GW, Pretorius JK, Babb TL. Influence of the type of initial precipitating injury and at what age it occurs on course and outcome in patients with temporal lobe seizures. J Neurosurg 1995; $82: 220-7$.

14. Mathern GW, Babb TL, Leite JP, Pretorius K, Yeoman KM, Kuhlman PA. The pathogenic and progressive features of chronic human hippocampal epilepsy. Epilepsy Res 1996; 26:151-61.

15. Shinoda S, Schindler CK, Meller R, So NK, Araki T, Yamamoto A et al. Bim regulation may determine hippocampal vulnerability after injurious seizures and in temporal lobe epilepsy. J Clin Invest 2004; 113:1059-68.

16. Kobayashi E, Li LM, Lopes-Cendes I, Cendes F. Magnetic resonance imaging evidence of hippocampal sclerosis in asymptomatic, firstdegree relatives of patients with familial mesial temporal lobe epilepsy. Arch Neurol 2002; 59:1891-4.

17. Kim WJ, Park SC, Lee SJ, Lee JH, Kim JY, Lee BI et al. The prognosis for control of seizures with medications in patients with MRI evidence for mesial temporal sclerosis. Epilepsia 1999; 40:290-3.

18. Montenegro MA, Ferreira CM, Cendes F, Li LM, Guerreiro CA. Clobazam as add-on therapy for temporal lobe epilepsy and hippocampal sclerosis. Can J Neurol Sci 2005; 32:93-6.

19. Rodin EA. The prognosis of patients with epilepsy. Springfield: Charles C. Thomas; 1968.

20. Sillanpaa M. Remission of seizures and predictors of intractability in long-term follow-up. Epilepsia 1993; 34:930-6.

21. Camfield C, Camfield P, Smith B, Gordon K, Dooley J. Biologic factors as predictors of social outcome of epilepsy in intellectually normal children: a population-based study. J Pediatr 1993; 122: 869-73.

22. Semah F, Picot MC, Adam C, Broglin D, Arzimanoglou A, Bazin B, et al. Is the underlying cause of epilepsy a major prognostic factor for recurrence? Neurology 1998; 51:1256-62.

23. Wiebe S, Blume WT, Girvin JP, Eliasziw M. A randomized, controlled trial of surgery for temporal-lobe epilepsy. N Engl J Med 2001; 345:311-8.

24. Yoon HH, Kwon HL, Mattson RH, Spencer DD, Spencer SS. Longterm seizure outcome in patients initially seizure-free after resective epilepsy surgery. Neurology 2003; 61:445-50.

25. Trevathan E, Gilliam F. Lost years: Delayed referral for surgically treatable epilepsy. Neurology 2003; 61:432-3.

26. Gilliam F, Kuzniecky R, Meador K, Martin R, Sawrie S, Viikinsalo $\mathrm{M}$, et al. Patient-oriented outcome assessment after temporal lobectomy for refractory epilepsy. Neurology 1999; 53:687-94.

27. Berg AT, Langfitt J, Shinnar S, Vickrey BG, Sperling MR, Walczak $\mathrm{T}$, et al. How long does it take for partial epilepsy to become intractable? Neurology 2003; 60:186-90.

\section{Endereço para correspondência:}

Fernando Cendes

Departamento de Neurologia - Faculdade de Ciências Médicas - UNICAMP

Caixa Postal 6111 - Cidade Universitária Zeferino Vaz

CEP 13083-970, Campinas, SP, Brasil

E-mail: fcendes@unicamp.br 